\title{
PREVENTING RADICALISM: ISLAMIC MODERATION AND REVITALIZATION IN THE BORDER
}

\author{
Ibrahim, Zaenuddin Hudi Prasojo, Sulaiman \\ Institut Agama Islam Negeri Pontianak \\ J1. Letjend. Soeprapto No. 19 Pontianak, West Kalimantan \\ E-mail: ab_irhamiy@yahoo.com
}

\begin{abstract}
The growing radical and extreme ideologies recently are not only a concern but also a threat to the social relations of harmony and human peace, including in the border region of Kapuas Hulu, Kalimantan. It is important to spread moderate Islamic teaching to counter this extreme ideology to the people in the border region of Kapuas Hulu. This research examines the roles of religious leaders and religious institutions in disseminating moderate Islam in the border region of Kapuas Hulu to counter the growing influence of radical-extremism. This research employs a qualitative method and the data from field research is presented descriptively. This research shows that religious leaders and religious institutions exist in almost every sub-district in the border region. They teach messages of Islamic moderation that include four principles namely the concept of tawasuth-moderate, tawazun-equality, tasamuh-tolerant, and i tidal. This principle must be strengthened as a foundation in behaving, acting, speaking, socializing, and living in the Indonesian nation and state. It is on these values and principles that religious leaders and religious institutions reinforce their role in preaching, guiding and fostering people in the border region.
\end{abstract}

Keywords:

Radicalism; Revitalization; Strengthen message; Islamic moderation; border region.

\section{Abstrak}

Berkembangnya faham radikal-ekstrim belakangan ini bukan saja menjadi kekhawatiran, melainkan ancaman bagi keharmonisan hubungan sosial dan kedamaian umat, tak terkecuali masyarakat kawasan perbatasan di Kapuas Hulu, Kalimantan. Terkait persoalan tersebut, penguatan pesan Islam moderat menjadi sangat penting dalam gerakan dakwah dan pembinaan umat di perbatasan, guna menangkal setiap pengaruh dan paham radikal-ekstrim berkembang. Penelitian ini bermaksud mengkaji peran tokoh agama dan lembaga keagamaan dalam membina umat di kawasan perbatasan, terutama dalam revitalisasi moderasi Islam, pesan dan praktek beragama dalam nilai-nilai lokal masyarakat nusantara. Penelitian ini menggunakan metode kualitatif dengan penyajian data secara deskriptif analitis. Hasil dari penelitian ini menunjukkan bahwa terdapat empat pilar moderasi islam yang mesti direvitalisasi dalam pemahaman dan praktek hidup masyarakat muslim di perbatasan meliputi nilai tawasuth-moderat, tawazunequality, tasamuh-toleran, dan i tidal. Pesan moderasi Islam inilah yang mesti direvitalisasi dalam materi dakwah dan pembinaan umat oleh para tokoh agama dan pimpinan lembaga keagamaan di kawasan perbatasan. Program revitalisasiberkaitandengan. memperkuat komunikasi dan koordinasi antar tokoh agama dan lembaga keagamaan di setiap kecamatan dan desa; melakukan kegiatan-kegiatan pembinaan keagamaan, baik melalui program berkelanjutan (rutinitas) maupun spontanitas; memperkuat pesan moderasi Islam dalam materi dakwah dan pembinaan umat. Dengan revitaliasasi moderasi Islam inilah, para tokoh agama dan lembaga keagamaan mampu menangkal faham radikal-ekstrim yang mempengaruhi umat di kawasan perbatasan.

Kata Kunci:

Radikalisme; Revitalisasi; Penguatan pesan; moderasi Islam; perbatasan 


\section{A. INTRODUCTION}

West Kalimantan is one of the border provinces with Malaysia. There are at least four official border crossings posts (Pos Lintas Batas or PLB) in the province of West Kalimantan, namely Sanggau Regency with Entikong PLB, Sambas Regency with ArukSajingan PLB, Bengkayang Regency with Jagoi Babang PLB, and Kapuas Hulu District with Nanga Badau PLB. There are also dozens or even hundreds of illegal border crossings between the two countries. This condition certainly gives positive and negative impacts on the social, cultural and economic affairs of the people of the two countries.

The positive impact of the border region with high social mobility triggers economic growth, especially in trading. ${ }^{1}$ However, the negative impact is far more threatening than that of positive impact, as it is related to the identity of the nation. For example, illegal trade $^{2}{ }^{2}$ illegal labor, thuggery, ${ }^{3}$ drug smuggling, human trafficking, ${ }^{4}$ the waning ideology of nationalism, the issue of terrorism, and the influence of radical-extremism. In short, these negative impacts bring great and serious threats to the future of people in the border region.

Rais Am of PBNU (great leader of NU) who is also the chairman of the Indonesian Ulema Council (MUI) KH. Ma ruf Amin once wrote an article published in the Republika news portal about this issue. In this article, he mentioned that in Indonesia nowadays, an understanding of religious radicalism and secular radicalism has been detected.

\footnotetext{
${ }^{1}$ Ibrahim, "Hubungan Penutur Bahasa-Bahasa Melayik: Kes Suku Iban Da Melayu Di Badau, Pulau Borneo" (Universiti Kebangsaan Malaysia, 2013).

${ }^{2}$ Reed L Wadley, "Community Cooperatives, 'Illegal' Logging and Regional Autonomy in the Borderlands of West Kalimantan," in State, Communities and Forests In Contemporary Borneo (ANU Press, 2006), https://doi.org/10.22459/SCFCB.07.2006.06.

${ }^{3}$ Reed L Wadley and M. Eilenberg, "Vigilantes and Gangsters in the Borderland of West Kalimantan, Indonesia," State, Communities and Forests In Contemporary Borneo, 2006.

${ }^{4}$ Wadley and Eilenberg.
}

Religious radicalism manifests in the ideas and movements with the aspiration to replace Pancasila as the principle of the nation to a religious-based nation. Meanwhile, secular radicalism is an idea and movement with the aspiration to delegitimize religion in the constitution and government. ${ }^{5}$

The growing understanding of radicalism ${ }^{6}$ and extremism ${ }^{7}$ has recently become a hot and disturbing issue in the social and religious life of the people, it has even presented the potential for conflict in the name of religion. ${ }^{8}$ Our society, which has been living in peace, harmony and mutual understanding, has been disturbed. People who have been able to live together with all differences in term of religious understandings, sects and beliefs havebeen disturbed by a group of people who has rigid understanding and attitude toward religion. As a result, they easily blame other groups as being heretic and even accuse others as infidel (takfiri).

This condition not only destabilizes religious values and beliefs of the people, but also undermines the roots of understanding of

${ }^{5}$ Muhyiddin, 'Kiai Ma'ruf Amin: Radikalisme Sekuler Ingin Agama Tak Berkontribusi Di Kehidupan," Republika Online, accessed April 14, 2019, https://www.republika.co.id/berita/duniaislam/islam-nusantara/17/03/27/onhbgc318-kiai-marufamin-radikalisme-sekuler-ingin-agama-takberkontribusi-di-kehidupan.

${ }^{6}$ The term radical-radicalism basicly means the opinion that aims at making changes drastically to exsisting norm using violent force when necessary. In term of religious radicalisme, it means rigid understanding of religious values and forcefully interfere to others' understanding in order that otehrs follow their understanding.

${ }^{7}$ Extrim-extrimismmeans strong belief to certain thought and many times their ideas are beyond the limit of reasonable practices. In term of religion, it refers to exsessive fanatism (ta $a s h u b$ ), easily blanes others as astray and infidel.

${ }^{8}$ Sumanto Al-Qurtuby, Lubang Hitam Agama: Mengkritik Fundamentalisme Agama, Menggugat Islam Iunggal (Yogyakarta: Rumah Kita, 2007). See Abdul Razak Abdulroya Panaemalae and Zaenuddin Hudi Prasojo, "Islam and the West: Tariq Ramadan and the Discourse of Religion of Peace for a Global Understanding," Al-Albab 5, no. 2 (2016): 237--250, https://doi.org/10.24260/alalbab.v5i2.507. 
tolerance among people who have been built for a long time in Indonesian history. For example, it was reported that a child boldly and arrogantly blamed and accused his parents as an infidel because his parents recited Yasin and dhikr in the congregation (the case in Nanga Suhaid \& Riam Panjang). ${ }^{9}$

Other examples reported that a khatib (preacher) brought a rousing and provocative sermon, blasphemed the local government and accused them of being a traitor to the people's trust and the like, thus triggering polemics (Putussibau case, discussion with Religious Instructors). Preaching by an ustadz (chaplain) blames several social and religious practices that have been carried out in the community, such as tahlilan, mass Qur'anic recitation after congregational prayers, (reciting) yasinan, pilgrimage to a tomb and so on, which became public objections (the case in Boyan Tanjung, discussions with Religious Instructor). Furthermore, in some other places, radicalextremism brought worrisome when it appeared in a brutal action in the name of "the truth of religious understanding," making acts of terrorism (the case of a pot bomb in South Tangerang).

The recent development of radicalextremism should not only become a concern but also be responded by concrete actions in the form of deterrence (prevention) of its influence in Indonesian society, especially the younger generation. In this context, the roles of religious leaders such as kiyai, ustadz, da $i$, and khatib and religious institutions are important in reinforcing Islamic messages and understanding that support peace and harmony in the society. ${ }^{10}$

\footnotetext{
${ }^{9}$ Suhaid and Riam Panjang, both are border areas in Kapuas Hulu Regency. If Riam Panjang is a representation of the Southern Cross route, Suhaid is a representation of the Kapuas River line.

${ }^{10}$ This condition is among the arguments used by those who could bring up the idea of preacher and preacher certification, because there is indeed an important role of preacher in influencing religious thought and understanding. Religious figures \& institutions are considered the most competent parties to the problem of the development of radical-extremism in
}

In this case, the task of religious leaders and institutions is crucial in directing the community whether they convey the message of a peaceful and tolerant understanding of the message of Islam or otherwise. Those understanding rooted in Islamic texts and the method that these religious leaders undertook in understanding these texts. ${ }^{11}$

This study examines the moderate understanding of Islam in the da'wah movement to strengthen people understanding of moderation in Islam. This moderation understanding of Islam is a way to counter the influence of radical and extreme understanding of Islam. Thus, it is important to train and revitalize religious leaders and religious institutions in order that they spread a moderate understanding of Islam. In this study, the focus will be spreading moderate understanding in the border region of Indonesia called Kapuas Hulu by Religious leaders and institutions.

The scheme of Research

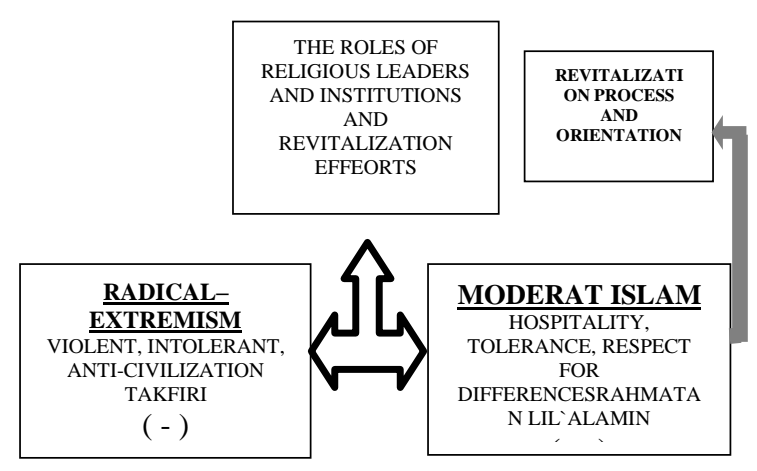

Figure 1: Logical Framework of the research

religious societies, including the concept of "jihad" which is understood to be a mere weapon.

${ }^{11}$ Islam Nusantara is a term used to refer to the Islamic characteristics of Indonesian Muslim communities. Said Agil Siradj defines Nusantara Islam as an Islamic practice that is rooted in the nation's history, which upholds tolerance, mutual respect, civilized and cultured. The teaching that accommodate tradition and culture. See Said Aqil Siradj, "Islam Indonesia Bukan Islam Arab,” Detik News, 2015. Azyumardi Azra called it Islam which teaches moderate messages or middle way (wasathiyah) in Azyumardi Azra, Islam Nusantara: Jaringan Global Dan Lokal (Jakarta: Mizan, 2002). 
This field study employed three main techniques to collect data namely, observation, interviews and Focus Group Discussion (FGD). The data collected is classified and interpreted using communicative data analysis.

Therefore this study specifically aims at finding a map of the existence of religious leaders and religious institutions, as well as their preaching and learning activities in strengthening the messages of moderate Islam. In addition, this research also aims at examining efforts of religious leaders and religious institutions and revitalizing their role in fortifying people from the influence of radical and extreme ideology in the border region. This article shows the important role of religious leaders and religious institutions in revitalizing the message of Islamic moderation to counteract the development of radicalextremism in the border region.

\section{B. RESULTS AND DISCUSSIONS \\ 1. Da'wah and Strengthening The message of Moderate Islam}

To strengthen the message of Islamic moderation means spreading the Islamic message of moderate Islam. It is deeply related to the condition of religious life and the influence of understanding spread among the people. The history of Indonesian Islam differs significantly from that of Middle Eastern countries where Islam first emerged. The process of Islamization in Indonesia adapted to local and cultural context. ${ }^{12}$

According to Wahid, Islam is revealed in accordance with the local and cultural context of the revelation to answer the problems of the people. Thus, understanding the message of Islam should accommodate the social and cultural context of the text revealed and the context of the text being read, including Indonesia. Consequently, it should differentiate between Islam and Arab, and does not mean that Indonesian Islam is not true Islam. Indonesian Islam is unique as it

\footnotetext{
${ }^{12}$ Abdurrahman Wahid, Islam Nusantara: Meluruskan Kesalahpahaman (Jakarta: Lembaga Ma`arif PBNU, 2015), 1.
}

accommodate Indonesian local culture as its identity. ${ }^{13}$

In this respect, the existence of extreme understandings of religion recently could separate Indonesian Muslims from its cultural roots. The extreme group usually blame other Muslim to have been gone astray and not the true Islam. Some of them act violently and in the form of terrorism in the name of establishing the true Islam. ${ }^{14}$ In this condition, religious leaders and religious institutions needs to strengthenthe concept of Islamic moderationas the basic values of Islamic message and spread it in their teaching and preaching activities, in particular in the border region. Therefore, this study discusses; 1 ) the map of the existence of religious leaders and religious institutions as initiator of da'wahat the border region; 2) religious activities and propaganda in the border region; 3 ) efforts to revitalize and strengthen the message of moderate Islamic in the border region.

\footnotetext{
${ }^{13}$ Islam Nusantara according to Said Aqil Siroj is Islam that was born and struggled and is rooted in the culture of the archipelago. It is differ significantly from that of in Arabic perspective, see Said Aqil Siradj, Islam Sumber Inspirasi Budaya Nusantara (Jakarta: LTN PBNU, 2015), 204.Islam Nusantara is an Ijtihad to dialogue between the essence of Islamic teachings in the style of Aswaja(Ahlussunnah wal Jama'ah) and the culture and civilization of the archipelago. Islam and Indonesian cultural context are not contradict to each other. ... in order to present Islamic teachings that are grounded in the archipelago, an inclusive Islamic teaching should be adjusted with a maritime and continental civilization of Indonesia, Isom Yusqi, "Islam Nusantara Bukan Agama Baru," in Islam Nusantara Meluruskan Kesalahpahaman, ed. Abdurrahman Wahid (Jakarta: LP Ma`arif NU, 2015).

${ }^{14}$ Ulil Abshar Abdalla, "Fundamentalisme Agama: Mungkinkah Mendirikan 'Kota Tuhan' Kembali?",' in Mengkritik Fundamentalisme Agama, Menggugat Islam Iunggal, ed. Sumanto Al Qurtuby (Yogyakarta: Rumah Kita, 2007), 11-18. See also Umi Sumbulih, "Gerakan Fundamentalisme Islam Di Malang: Studi Atas Hizbut Tahrir, Majlis Mujahidin, Dan Arimatea," Jurnal Istiqra 6, no. 1 (2007): 1-50. See also Ahmad Zainul Hamdi, "Radikalisme Islam Melalui Institusi SemiNegara: Studi Kasus Atas Peran MUI Pasca-Soeharto," JurnaL Istiqra 6, no. 1 (2007): 85-126.
} 


\section{a. The Map of Existence of Religious Leaders and Religious Institutions}

This section elucidates the existence of religious leaders and religious institutions in the border region, specifically the Kapuas Hulu Districts. It has been known that Kapuas Hulu districts whose area has direct adjacent to Malaysia, precisely Badau (Indonesia) which is close to Lubuk Antu Sarawak (Malaysia). As a district region, there are several religious leaders and religious institutions recognized by the community. These leaders and institutions are trusted to educate and guide the community in terms of religion.

The religious leaders have the authority to teach religious knowledge to the community. These religious leaders are often asked for advice and guidance from the community. These religious leaders area central figures in the community and thus their position is important.

Several roles they play in the community include community leader, teacher of the Quran, imam of the mosque, school teacher and many others. In principle, those who are called religious leaders are those who have better religious knowledge who guides the community in spiritual life.

As a fairly extensive border area, Kapuas Hulu is divided into three zones: South, North, and Kapuas. ${ }^{15}$ The religious leaders in this area served not only in the district area but also in sub-district, villages, and hamlets. The religious leaders identified in this area are ustadz H.M. Basri (Sei. Terus-Hulu Gurung), $u s t a d z$ Ehsan (Menendang-Pengkadan), ustadz M. Taha (Temuyuk-Bunut Hulu), ustadz H. Sutardi (Jongkong), ustadz Karyadi and ustadz Sukiman (Badau), to name a few.

Figure 2 is the map of Kapuas Hulu Districts that contains three areas:

\footnotetext{
${ }^{15}$ Ibrahim, "Hubungan Penutur Bahasa-Bahasa Melayik: Kes Suku Iban Da Melayu Di Badau, Pulau Borneo.”
}

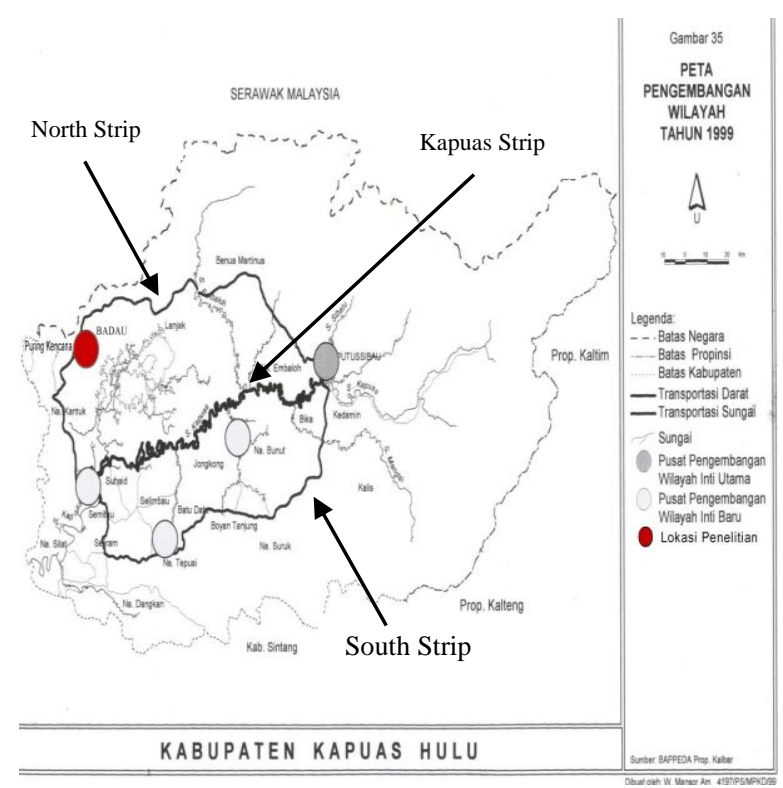

Figure 2: Map of Kapuas Hulu

From data collected, it can be found that the existence of religious leaders spread in every village and hamlet. Their presence is significant in empowering the people in the border region.

\section{Religious Activities and Da'wah at the Border}

There are many religious activities carried out by religious leaders and religious institutions in the border region in Kapuas Hulu Regency. The activities can be categorized as routine activities and spontaneous.

Various activities of religious leaders include, among other things, giving religious guidance for the people around their residence and preventing people from negative influences in the border region. This can be seen from the statement of Ustadz Sukiman, the former head ofKUA in Badau District when the FGD was conducted:

...In Badau there are several routine religious activities. Some of them were the establishment of several majlis taklim (religious gathering) in the surau-surau (small mosques), especially the women taklim (women religious gathering). There is also TPQ (Quranic School) or TPA (Qur'anic Learning Centre). In mosque alHidayahfor example there are 
approximately 100 students who learn the Qur'an. We have done all this to fortify the people from any bad influence related to religious understandings... ${ }^{16}$

Religious leaders often become a reference and a place for the community to ask questions related to religious issues as well as other general matters. The religious leaders identified in this research categorizes as preachers, religious teachers, Quranicteachers and mosque imams. They are served in every village in the border area.

Religious institutions identified in this research namelyOffices of Religious Affairs (KUA), served as a religious institution that gives advice and guidance, especially on marriage and divorce. Others are Islamic boarding school and Madrasa, mosque management, madrasa management, institutions and supervision of customs. At the district level, religious institutions that always carry out their role in religious formation are the Indonesian Ulema Council (MUI), Nahdlatul Ulama (NU), Muhammadiyah, Da'wah Council, Islamic Da'wah Institute, and some of the affiliations of Islamic political parties.

\section{The Efforts to Revitalize and Strengthen the Message of Islamic Moderation at the Border}

Of the many religious figures and religious institutions, there are still many strategic religious roles that cannot be carried out optimally. This means that there are still many religious issues that have not been absorbed properly by the community. In some places, the role and existence of religious leaders and religious institutions are still ignored and underestimated. Therefore, revitalization efforts are needed to face global challenges, especially with the coming influence of radical-extremism. The understanding of

\footnotetext{
${ }^{16}$ Sukiman, interview by Ibrahim, Badau, Kapuas Hulu, on May 27, 2018.
}

moderate Islam should be disseminated as the identity of Indonesian Islam. ${ }^{17}$

These revitalization efforts are aimed more at strengthening the role of religious leaders and religious institutions in fostering the Ummah (aspects of $d a ` i$ and the mad $u$ or communicators and the communicants). Likewise, the reinforcement of the message of Moderate Islam is more directed at the content or material of the communication of ad-da'wa given by religious leaders and religious institutions in fostering people in the border region.

This study focuses on the analysis of what and how the messages of moderate Islam are; What and how the messages of moderate Islam are given and delivered in the process of fostering the Ummah; What and how the strategic steps are planned and carried out by $d a^{\prime} i$ (religious leaders and religious institutions) in the empowerment process of the people in the border region. Special attention is given against the possible influence of radical-extremism that became vigilance of the nation today.

In this case, the preachers (religious leaders and religious institutions) should not deliver the message in their da'wah related to general topic but to be specific addressing moderate understanding of Islam and the danger of rigid understanding that could lead to radicalism.

Strengthening the message of Moderate Islam in the da'wah and fostering of the Ummah in the border region is urgent to provide a fortress (filter) for the people from the influence of radical-extreme ideology that

\footnotetext{
${ }^{17}$ The term Islam Nusantara raised polemic among several people. Some of them said that it brings up a new faction of Islamic ideology and streams. In essence, this paper will not bring the reader to the debate. The author agrees with Buya Yahya, a charismatic scholar from Cirebon. According to him, there is no problem in the term of Nusantara Islam, it becomes a problem when it is used by certain people for certain interests, so that it is understood incorrectly, cited in Muhammad Fahmi, "Diskursus Islam Nusantara Dalam Refresentasi Media Massa," Jurnal Komunikasi Islam 7, no. 1 (2017): 24-25.
} 
is contrary to the values of moderation of Indonesian Islam.

With all the concepts and objectives above, this study presents interesting information, data, and facts, which were analyzed in order to find the efforts to strengthen the message of Moderate Islam in fostering the Ummah in the border region.

The revitalization efforts are indeed related to several programs and plan to increase the roles and functions of religious leaders and religious institutions in fostering people in the border region. Some of the programs are to intensify communication and coordination between religious leaders and religious institutions with government, police, and military. This collaborative attempt aim at strengthening a better synergy in the community development program. All in all, the problem of the people is not only a matter of religion but also a matter of social, political, economic, cultural and many others. Ustadz Masni from the Nanga Badau Resort police stated:

...because of that, in my opinion, the Badau people need to build good coordination and communication, especially with the police on many issues, as what Ustadz Shalihin said that Santoso's [refers to former jihadist] followers are here, ....so we can immediately explore the information ${ }^{18}$

In the context of empowerment and revitalization efforts in the community, the religious leaders and religious institutions instructed that every element of the community needs to work together and know procedures to be done in anticipating misbehave conduct. This was reflected in the statement of Ustadz Sukiman, a retired (Head) of the Office of Religious Affairs (KUA) Nanga Badau:

Ladies and gentlemen, if you meet with cases like that (referring to the statement of other sources before), you should listen first, study carefully, and then report it to the authorities or religious leaders. Do not

\footnotetext{
${ }^{18}$ Masni, interview by Ibrahim, Badau, Kapuas Hulu, on May 27, 2018.
}

immediately deny or make a reaction. Moreover, if we do not understand the problem well and adequate, don't easily believe the understandings, like the opinion of Jihad bombs with the reward of getting to heaven, that's a heresy. ${ }^{19}$

Still, in the efforts to revitalize the participation of all parties in empowering the community and to enact the functions of religious institutions in the border region, Adeni(head of the Menari Hamlet Nanga Badau) reminded that:

...For all residents, if there are new people coming to our region, it is better to report to the local authorities, at least the head of $R T$ or hamlet/village. Or you can even report yourself to the nearest police station. This is important to eliminate suspicion and even to filter unsure people, who could influence the local understanding. ${ }^{20}$

The efforts of revitalization are also conducted by religious leaders and religious institutions in villages, sub-districts or district levels. Abdurrahman, an official in the Ministry of Religious Affairs of Kapuas Hulu District stated:

The majority of us in Kapuas Hulu are belong to Ahlussunnah Waljama'ah...The people should always be monitored by religious leaders in sub-districts. If there is a somewhat different understanding, we will conduct direct training. ${ }^{21}$

Furthermore, according to him, good coordination and communication among all parties, especially among religious leaders and religious institutions, are essential for the efforts to strengthen the role and function of religious empowerment of the people:

...For example, in Badau there was a rumorof rejection to the construction of a boarding school by the residents. When we checked, it was more due to personal

\footnotetext{
${ }^{19}$ Adeni, interview by Ibrahim, Badau, Kapuas Hulu, on May 27, 2018.

${ }^{20}$ Adeni, interview by Ibrahim, Badau, Kapuas Hulu, on May 27, 2018.

${ }^{21}$ Abdurrahman, interview by Ibrahim, Putussibau, Kapuas Hulu, on May 28, 2018.
} 
problems (interests) between the residents and the people who undertook the construction of the boarding school. So, the rumor of rejection on the basis of religious differences is not true. However, in order to avoid the bigger problem, we, from the Ministry of Religious Affairs, decided to suspend the program in Badau. ${ }^{22}$

Imam Shabirin, a member of MUI and Regional House of Representative, also mentioned that good coordination and communication among religious leaders enhanced the empowerment of religious guidance process. ${ }^{23}$ Several religious leaders who respond in the effort of empowering the people in their regions are H.M. Basri (Chairman of the District MUI) in Nanga Terus and its surroundings; Ustadz $\mathrm{H}$. Mansuruddinin Nanga Semangut and its surroundings; H.M. Arsyad and H. M. Aniin Jongkong and its surroundings, to name a few. Every region has its own religious leaders assisting the community related to religious matters and mostly played by the official at MUI Kapuas Hulu.

It is obviously understandable from the statement above concerning the efforts to revitalize the role of religious leaders and religious institutions in empowering people in the border region: First, it is important that all parties, all citizens from all elements including religious leaders and institutions build good communication and coordination. And more important still is to optimize and implement the programs of empowering people of the border region.

Second, All parties and all citizens from all elements need to be vigilant of the presence of new people who bring new ideology that considered the potential to disintegrate the harmony of the people. Intensive communication and coordination are important steps in revitalizing and strengthening

\footnotetext{
${ }^{22}$ Iman Shabirin, interview by Ibrahim, Putussibau, Kapuas Hulu, on May 28, 2018..

${ }^{23}$ Suryadi, interview by Ibrahim, Putussibau, Kapuas Hulu, on May 28, 2018.
}

messages of Islamic moderation in the border region.

Third, it is important to continue strengthening communication networks and coordination between religious institutions and government agencies starting from the district, sub-district, village, hamlet to RT level in the effort of revitalizing and strengthening the message of Islamic moderation. As a result, the effort of empowering the people by the religious leaders and religious institutions run synergically and continuously in the border region.

Fourth, the next revitalization effort can also be seen from the good coordination and communication among religious leaders and institutions, resulting in the agreement on the division of tasks and responsibilities for the development of the people in their respective places in the border region commanded by the District MUI. People must put their trust to MUI District for the highest decision regarding any differences of understanding and religious schools growing in the community and for Fatwa to the Provincial MUI Fatwa assembly.

For these reasons, it is presumably necessary to identify and recognize several factors that are potential in triggering the disintegration of the people, mainly caused by the emergence of radical-extreme ideology in the border region.

\section{Potential disintegration and radical- extremism at the border}

The efforts to revitalize the role of religious leaders and religious institutions in strengthening the messages of Islamic moderation are intended to deter Muslims from radical extremist ideology potential that influences the relationship and harmony of people in the border region. Basically, Islam around the border region in Kapuas Hulu is only belonged to Ahlussunnah wal Jama`ah, as revealed by Iman Shabirin:

Actually, this region (Putussibau), Semitau and Jongkong are generally disciples of Pak Ustadz (read: Ustadz Haji Ahmad bin Haji 
Abu Bakar). Therefore religious teaching is almost the same and there was no problem. What becomes a problem is when new teachings from an outsider are introduced to the people. ${ }^{24}$

Furthermore, Iman Shabirin explained that it is reported that in Jongkong a new understanding is sought of Tauhid AlWahidiyah that categorized as Shi'a. Likewise, in Putussibau, the influence of Wahabi Salafi is also identified as this understanding blames many religious rituals as bid'ah (heresy), tahrim (forbiddance), takfir (infidel) and so on. This group is too hasty to accuse other religious practices as astray, even to forbid and to accuse others as infidel when other understanding differs from that of their own. ${ }^{25}$

Such ideologies are contradicted to the mainstream religious affiliation and understanding in Kapuas Hulu as taught by Ustadz Haji Ahmad. Therefore, according to Iman Shabirin, serious efforts are needed in the form of revitalizing the role of religious leaders and religious institutions in protecting people from the influence of strange and distorted ideas. Another important aspect that must be instilled in the ummah to fortify these influences is strengthening the messages of moderate Islam, as the basis of religious and Islamic values of the people.

It is also necessary for religious leaders and religious institutions in the border region to be watchful of any potential disintegration in the community. This is in line with the statement of Ustadz Suryadi, Secretary of the District MUI during FGD at Ustadz Aziz Jalaluddin's house:

The complication of misunderstanding can be solved by KUA and MUI through a routine study conducted in many places, in sub-districts, even in villages. This study program is led directly by the Chairperson

\footnotetext{
${ }^{24}$ Iman Shabirin, interview by Ibrahim, Putussibau, Kapuas Hulu, on May 28, 2018.

${ }^{25}$ Iman Shabirin, interview by Ibrahim, Putussibau, Kapuas Hulu, on May 28, 2018.
}

of the district MUI (Ustadz H.M. Basri) and has been running for more than two years. $^{26}$

Furthermore, according to him, there are several indications regarding the existence of a new religious understanding spread by grouplike Wahabi Salafiin Nanga Suhaid, Tauhid Al-Wahidiyah in Jongkong and Temuyuk, Bunut Hulu. Their understanding differs significantly from that of the majority of Muslims in this region.

According to Suryadi, this group teaches the understanding of shari'ah, sufism, ma'rifat, and hakikat which are very different from what people have known. They teach those understandings to ordinary people. Therefore, it becomes a concern that their understanding is distorting and unsettling. The main source of their teachings (especially Tawhid AlWahidiyah) is Adam Troy Effendi 's book entitled "Ilmu Sedikit Untuk Segalagalnya..."27

Furthermore, concerning the teaching of Tawheed Al-Wahidiyah, Abang Muhammad Shaleh, Head of KUA in Jongkong District, explained:

In CentralJongkong there is indeed a strange religious understanding, namely the understanding of Tawhid Al-Wahidiyah. The KUA facilitated the settlement of the case by presenting it to the district MUI to be studied and find a solution. Alhamdulillah, It is being processed and waitfor the decision of the provincial MUI fatwa regarding the status of this group. Lately, we have heard that this understanding has also spread to other regions in the Southern Crossings such as Landau Apus, Temuyuk and Sukamaju. The instructor is from Pontianak. In Pontianak, this teaching has basis in Pusaka Madinah study group... ${ }^{28}$

\footnotetext{
${ }^{26}$ Aziz Jalaluddin, interview by Ibrahim, Putussibau, Kapuas Hulu, on May 28, 2018.

${ }^{27}$ Suryadi, interview by Ibrahim, Putussibau, Kapuas Hulu, on May 28, 2018.

${ }^{28}$ Abang M. Saleh, interview by Ibrahim, Putussibau, Kapuas Hulu, on May 30, 2018.
} 
The statement of the head of KUA immediately received support from Ibrahim, chairman of the District PHBI:

I agree with the officer of KUA who said that the religious understanding of Tauhid Al-Wahidiyah and his group was very disturbing. Their presence here (Jongkong) is without permission. Consequently, people are confused and anxious...the characteristics of the teachings of this understanding are evident, for example, in prayer (Friday), the followers sit at the back row and noisy. The way they stand in praying is also different from our usual prayers. Their bodies are bent up to 30 degrees. $^{29}$

Besides the understanding of Wahabi Salafi and Tauhid Al-Wahidiyah, there are indications of other understandings that are also troubling in the midst of religious communities (ummah) in the border region, as revealed by Ustadz Suherman, a religious counselor in Jongkong District.

In addition, in Kelampai (a village in the hinterland of Jongkong upstream) there is also a new religious issue, which is about the raka'at of prayers in Taraweeh. There is a group of people (young people) who conveniently change the habits of Taraweeh prayer in the community from 20 raka'at to 8 raka'at. The basis for the change is very simple, there is no cleric or imam who can lead Taraweeh prayer 20 raka'at because of limited memorization of surah in the Qur'an. Another reason was carried out by the voting mechanism of the mosque management. That's what's strange. ${ }^{30}$

Considering many issues of various understandings and the potential to disintegrate the people, KUA officer of Jongkong District (Abang Muhammad Shaleh) reminded every religious leader and religious institution to guard the people. In addition, to

\footnotetext{
${ }^{29}$ Ibrahim, interview by Ibrahim, Putussibau, Kapuas Hulu, on May 30, 2018.

${ }^{30}$ Suherman, interview by Ibrahim, Putussibau, Kapuas Hulu, on May 30, 2018.
}

also vigilant of the possible party which has uncertain origins and unsure religious understandings to spread its understanding to the people in their respective regions. Especially, if the understanding taught is considered not in accordance with the characteristics of the people and the mainstream religious school of Ahlussunnah wal jama ah which has been practiced for so long in this region.

\section{Revitalizing Islamic Moderation to Prevent Radical-Extremism in the Border Region}

The following section presents discussions on: first, the substance of the message of Islamic moderation and/or Islam of the Archipelago famous with the term Islam Nusantara in comparison (vis a vis) with radical-extreme ideology); second, Islamic moderation as an antidote to the growing influence of radical-extremism in the border region.

\section{a. The Substance of Message of Islamic Moderation-Islam Nusantara}

This study started from the analytic map of preventive issues and solutive issues in order to examine the substance of the message of the Islamic moderation-Islam Nusantara versus radical-extremism.

Table 1 presented becomes a reference in examining radical-extreme issues and strengthening the messages of Islamic moderation by religious leaders and religious institutions in the border regions. This is closely related to the term Moderate Islam which has become an important discourse in the last decade. Many people in the country declare themselves as the pioneers of moderate Islam. In short, moderate Islam echoed by many parties lately is a typical style of Indonesian religious diversity or the way of Islamic life of Indonesian people. Therefore, another term that often comes to the surface along with the term Islamic moderation is Islam of the Archipelago (Islam Nusantara).

Thus, what is the substance of the teachings of Islamic moderation or Islamic Nusantara 
(Indonesian Islam)? Muhammad Guntur Romli and the Ciputat School Team in their book entitled Islam Kita Islam Nusantaranotes that there are at least seven domains of the substantial values of Islam Nusantara; ${ }^{31}$ Islam Nusantara promotes harmony with local culture (as practiced by Walisongo).Islam which is able to respect diversity through its relationship with local factors, with the sharia foundation adopting good cultural (adat) values, with three attitudes: a) tolerant (allowing and respecting diversity); b) forming subcultures (strongholds) in society such as pesantren; c) make gradual changes and avoid violence.

Table 1 is a table of analysis of preventive issues - solutive messages: (Radical-extremism vs. Islamic moderation). ${ }^{32}$

\begin{tabular}{|c|c|c|}
\hline $\mathrm{NO}$ & $\begin{array}{l}\text { Preventive } \\
\text { Issues } \\
\text { (Radicalist- } \\
\text { Extremist) }\end{array}$ & $\begin{array}{l}\text { Solutive Messages } \\
\text { (Moderate Islam) }\end{array}$ \\
\hline 1 & $\begin{array}{l}\text { No ceremonies- } \\
\text { No presenting } \\
\text { arm for flags, } \\
\text { rejecting } \\
\text { Pancasila, } \\
\text { rejecting PPKN } \\
\text { and NKRI }\end{array}$ & $\begin{array}{l}\text { Developing the attitude } \\
\text { and spirit } \begin{array}{l}\text { of } \\
\text { nationalism- } \\
\text { wathan minal iman }\end{array}\end{array}$ \\
\hline 2 & $\begin{array}{l}\text { Isolating } \\
\text { themselves from } \\
\text { communication } \\
\text { with family }\end{array}$ & $\begin{array}{l}\text { Build a harmonious- } \\
\text { communicative family }\end{array}$ \\
\hline 3 & $\begin{array}{l}\text { Anti-social, } \\
\text { excluding the } \\
\text { communication } \\
\text { with others - the } \\
\text { community }\end{array}$ & $\begin{array}{l}\text { Build a social life, open, } \\
\text { mutual help }\end{array}$ \\
\hline 4 & $\begin{array}{l}\text { Easily-accusing } \\
\text { others as bid'ah, } \\
\text { even condemn } \\
\text { others in } \\
\text { worshipping }\end{array}$ & $\begin{array}{l}\text { Understanding } \\
\text { nature of diversity, the } \\
\text { nature of truth and } \\
\text { openness (Q.S. 5: 48; } \\
\text { Q.S. 49: 13, etc.) }\end{array}$ \\
\hline
\end{tabular}

\footnotetext{
${ }^{31}$ Mohamad Guntur Romli, Islam Kita, Islam Nusantara: Lima Nilai Dasar Islam Nusantara (Tangerang: Ciputat School, 2016).

${ }^{32}$ The analysis of this table derrived from various resources, specificallyIbrahim and Imron Muttaqin, "Revitalisasi Peran Tokoh Agama Dan Lembaga Keagamaan Dalam Penguatan Pesan Islam Moderat Di Wilayah Perbatasan" (IAIN Pontianak, 2018).
}

\begin{tabular}{|c|c|c|}
\hline & $\begin{array}{l}\text { such as tahlilan, } \\
\text { grave } \\
\text { pilgrimage, and } \\
\text { sholawatan }\end{array}$ & \\
\hline 5 & $\begin{array}{l}\text { Egocentric in } \\
\text { judging, } \\
\text { frequently } \\
\text { criticizing } \\
\text { others, even } \\
\text { accusing others } \\
\text { as unbelievers } \\
\end{array}$ & $\begin{array}{l}\text { Religiously inclusive, } \\
\text { muhasabah } \\
\text { introspective, fastabiqul } \\
\text { khairat, and do not take } \\
\text { the rights of Allah }\end{array}$ \\
\hline 6 & $\begin{array}{l}\text { Tend to be old- } \\
\text { fashioned and } \\
\text { intolerant of } \\
\text { others who have } \\
\text { different views } \\
\text { or beliefs }\end{array}$ & $\begin{array}{l}\text { Promoting tolerance and } \\
\text { lita `arafu (Q.S. 49: 13) }\end{array}$ \\
\hline 7 & $\begin{array}{l}\text { Disliking and } \\
\text { hating moderate } \\
\text { Islamic } \\
\text { organizations } \\
\text { such as NU and } \\
\text { Muhammadiyah }\end{array}$ & $\begin{array}{l}\text { Understanding the } \\
\text { characteristics of Islam } \\
\text { of the Archipelago - } \\
\text { Islam in the Indonesian } \\
\text { way, including its } \\
\text { religious organizations }\end{array}$ \\
\hline 8 & $\begin{array}{l}\text { Hating, berating, } \\
\text { even making fun } \\
\text { of scholars who } \\
\text { disagree with } \\
\text { their beliefs, } \\
\text { despite having a } \\
\text { high religious } \\
\text { scholarship }\end{array}$ & $\begin{array}{l}\text { Respecting for the } \\
\text { ulema as a } \\
\text { warasatulanbiya, not } \\
\text { making fun of anyone's } \\
\text { religion and beliefs }\end{array}$ \\
\hline 9 & $\begin{array}{l}\text { Supporting, even } \\
\text { affiliating with } \\
\text { extreme } \\
\text { organizations }\end{array}$ & $\begin{array}{l}\text { Supporting and joining } \\
\text { moderate organizations }\end{array}$ \\
\hline
\end{tabular}

Islam Nusantara transforms its message gradually, non-radical or extreme, avoids violent methods and seeking "middle ground", "compromise" and "synthesis" with the local culture. Islam that transformed into the power of the nation and its development. Its Da'wah includes education, social services, arts and culture, and other cultural activities. Islam Nusantara provides moderate (tawasuth), and tolerant (tasamuh) values of Islam. ${ }^{33}$

In the context of nationality, Moderate Islam is an Islamic behavior suitable to Indonesian culture which is often known as IslamNusantara. In other words, Islam

\footnotetext{
${ }^{33}$ Mohamad Guntur Romli, Islam Kita, Islam Nusantara.
} 
Nusantarais actually manifested in the religious practice of Muslims in Indonesia. In Cirebon, acceptance of the pure teachings of Islam does not necessarily eliminate traditional rituals, worshipping rituals, myths, and the grave pilgrimage for example, which are still practiced by the Muslim community to this day. ${ }^{34}$ Likewise, Javanese Muslims in Suriname also practice the values of Islamic teachings as well as the traditions of Slametan, ${ }^{35}$ and the Muslim community in Bima Sumbawa still preserves local traditions along with their religious practices. ${ }^{36}$ These are evidence that Islamic teachings are accepted and practiced alongside traditions and local culture of the Indonesian people, as intended by the terminology of Islam Nusantara.

Therefore Said Aqil Siroj reminded that the study of Islam of the Archipelago is not just a study of the Islamic region, but more importantly, is a study of the Islamic values that exist in this region which has been growing and developing for centuries. This civilization was developed by saints and scholars throughout history, starting from the Pasai Ocean, Malacca, Palembang, Banten, Java, Pontianak, Bugis, Ternate, Tidore in Maluku and Papua. ${ }^{37}$

Sarlito Wirawan Sarwono, a professor and also a psychologist, strongly supports the views of Islam of the archipelago. According to him, Islam was revealed from Allah but when practiced by humans on earth, it inevitably has to embrace the culture. That is

\footnotetext{
${ }^{34}$ Abdul Ghafur Muhaimin, "The Islamic Traditions of Cirebon" (Australian National University, 2006). See also Busro Busro and Husnul Qodim, "Perubahan Budaya Dalam Ritual Slametan Kelahiran Di Cirebon, Indonesia," Jurnal Studi Agama Dan Masyarakat 14, no. 2 (2018): https://doi.org/10.23971/jsam.v14i2.699.

${ }^{35}$ Moh Khusen, "Contending Identity In The Islamic Ritual: The Slametan among Surinamese Javanese Muslims in The Netherlands," Al-Jami'ah: Journal of Islamic Studies 43, no. 2 (November 30, 2005): 283, https://doi.org/10.14421/ajis.2005.432.283-308.

${ }^{36}$ Muhammad Adlin Sila, "Menjadi Muslim Di Bima Sumbawa Indonesia: Keanekaragaman Politik Dan Budaya” (Australian National University, 2014).

${ }^{37}$ Siradj, Islam Sumber Inspirasi Budaya Nusantara.
}

why in West Sumatra there is a matriarchal Islam, in Java, there is a mosque tower shaped like a Hindu temple in Kudus, in the fountain where the ablutions are head-engraved with statues (and none of the devotees later worship it), and in Tapanuli there is Islam that is exactly the same as Christians Batak in essence. Islam of the archipelago is the application of Islamic teachings in the way of the Indonesian Muslim community which cannot be found in Afghanistan or Pakistan, or even Saudi Arabia. ${ }^{38}$

In such a perspective, what we have to understand about the concept of Islam Nusantara, according to Prof. Isom Yusqi, is a dialectical process between the Shari'ah and the local culture of the archipelago. It is not the process of conversion or assimilation ${ }^{39}$ because it will jeopardize the true meaning of Islam. The Qur'an is in Arabic and it will always be. The recitation in the prayer will always in Arabic. The translation of the Qur'an will never replace the Qur'an. However, its translation is important to understand its meaning. ${ }^{40}$

Thus Islamic moderation developed in Indonesia archipelago is based on the primary source of Islam with the accommodation of Indonesia realities and character.

\section{Islamic Moderation as an Antidote to Radical-Extremism}

Strengthening the message of Islamic moderation as a substance for the program of the revitalization of the da'wah movement and the empowerment of the ummah in the border area is based on the thought that:

First, Islamic moderation is the style and identity of multicultural Islamic societies such as in Indonesia. Therefore, Islam of the archipelago is supposed to be suitable or in accordance with religious and national

\footnotetext{
${ }^{38}$ Arifin Junaidi, "Islam Nusantara Adalah Islam Kita," in Islam Nusantara Meluruskan Kesalahpahaman, ed. Abdurrahman Wahid (Jakarta: LP Ma`arif NU, 2015), 102.

${ }^{39}$ Yusqi, "Islam Nusantara Bukan Agama Baru."

${ }^{40}$ Junaidi, "Islam Nusantara Adalah Islam Kita."
} 
characteristics. On the other hand, radicalextremism that becomes the problem today actually alienates people from the characteristics of locality in religion. In other words, it does not accommodate the religiosity and pluralistic multicultural way of Indonesian society.

Second, the values of Islamic moderation and radical-extremism are contradictory, thus, strengthening one of the values is believed to be an antidote to the values of the other. That is the reason why Islamic moderation (the message of Moderate Islam) is chosen as the power of the people to avoid the influence of radical-extremism.

Third, Thus, the role of religious leaders and religious institutions is crucial. It is necessary to strengthen (revitalize) the role of both in conveying messages of Islamic moderation in the development of the people in the border region.

The values of Islamic moderation are in accordance with the teaching of Ahlussunnah Waljama ah (especially from NU) which have four basic pillars, namely tawasuth (moderate), tawazun (equal), tasamuh (tolerant) and i tidal (in favor of truth and justice). The four noble pillars are the foundation of attitude, action, speech in the community, nation, and state. ${ }^{41}$

Islamic moderation is actually have been manifested in Indonesian daily practices. In the remote area of Ulu Kapuas, for example, the tradition of Pangil Malayis a ritual that combines Islam and local culture. ${ }^{42}$ Other practices identified are the tradition of buma, tepungtawar and village treatment. ${ }^{43}$

In sum, the values of moderation, tasamuh, tawazun, and itidal are essentially the core of the message of Islamic moderation that is

\footnotetext{
${ }^{41}$ Yusqi, "Islam Nusantara Bukan Agama Baru."

${ }^{42}$ Ibrahim Ibrahim, "Al-Ṭuqūs Wa 'alāqatuhā Bi Huwīyat Muslimī Ulu Kapuas, Kalimantan AlGharbīyah," Studia Islamika 25, no. 3 (December 1, 2018): 543-88, https://doi.org/10.15408/sdi.v25i3.6579.

${ }^{43}$ Ibrahim Ibrahim, "Contiguity of Islam and Local Tradition on the Hinterland Malays of West Kalimantan," Ulumuna 22, no. 2 (December 28, 2018): 277-300, https://doi.org/10.20414/ujis.v22i2.286.
}

continuously strengthened (revitalized) by religious leaders and religious institutions in their da'wah. With the revitalization of Islamic moderation, religious leaders and religious institutions are able to provide a shieldstronghold for the people in counteracting the influence of radical-extremism in the border region. Thus, the potential for disintegration in the community in relation to radicalextremism in the border region can be overcome immediately. In contrast, any effort of da'wah and religious empowerment is directed to support the revitalization of Islamic moderation through the strategic role of religious leaders and religious institutions in order to counteract the influence of radicalextremism in the border region.

\section{CONCLUSIONS}

In general, this research results in an understanding that the emergence of various issues of nationality in the border region is caused by the growing influence of radicalextremism. This condition is the reason for the importance to strengthen the message of Islamic moderation by religious leaders and religious institutions in the border region. The messages of Islamic moderation basically teaches four principles of religious life and nationality as a characteristic of the Islamic community of Indonesia known as Islam Nusantara are the concept of tawasuthmoderate, tawazun-equality, tasamuh-tolerant and itidal). This principle must be strengthened as a foundation in behaving, acting, speaking, socializing, and living in the Indonesian nation and state. It is on these values and principles that religious leaders and religious institutions reinforce their role in preaching, guiding and fostering people in the border region. In more specific, this research concludes: First, with their respective capacities, religious leaders and religious institutions exist in almost every sub-district in the border region. Some of them even existed at the village level. These religious leaders occupy positions as clerics, mosque priests, Quranicteachers and many others who become leaders in religious activities to 
empower the people. The religious leaders identified in this research also served the position as mosque administrators, traditional leaders, heads of the Office of Religious Affairs (KUA), Heads of Ministry of Religious Affairs (Kemenag), and head of prominent organizations like MUI, NU, Muhammadiyah, and so on.

These religious leaders identified in this research are Ustadz H.M. Basri (Sei. TerusHulu Gurung), Ustadz Ehsan (MenendangPengkadan), Ustadz M. Taha (Temuyuk Bunut Hulu), Usadz H. Sutardi (Jongkong), Ustadz Karyadi and Ustadz Sukiman (Badau), and so on.

Second, Da'wah activities and empowerment of the people carried out by religious leaders and religious institutions in the border region are in two forms: routine continuous, and spontaneous- situational activities. Some of the routine activities are conducted in Majlis Taklim for women held from the village to hamlet level, sub-district to district level; Majlis Taklim on fiqh and worship held every week under the coordination of the District MUI in several sub-districts in the border region; Teaching and learning the Qur'an (TPQ-TPA); training people through Friday sermons in every mosque in the border region.

Some of spontaneous - situational activities are religious lectures in the moments of commemorating Islamic holidays; when resolving religious problems that occur in the midst of the people (when there are certain cases); sakinah family coaching through the role of KUA (in each sub-district in the border region), both by religious leaders in person and through da'wa institutions (such as MUI, NU, Muhammadiyah, and KUA).

Third, the efforts to revitalize the da'wah movement should focus on spreading moderate Islam as the basic values of Islam. Some of the manifestations of the revitalization effort is to intensify communication and coordination between religious leaders and related parties such as the government, police, and military to optimize the implementation of the tasks and functions of respective religious leaders and institutions.

\section{REFERENCES}

Abdalla, Ulil Abshar. "Fundamentalisme Agama: Mungkinkah Mendirikan 'Kota Tuhan' Kembali?"." In Mengkritik Fundamentalisme Agama, Menggugat Islam Iunggal, edited by Sumanto $\mathrm{Al}$ Qurtuby. Yogyakarta: Rumah Kita, 2007.

Abdulroya Panaemalae, Abdul Razak, and Zaenuddin Hudi Prasojo. "Islam and the West: Tariq Ramadan and the Discourse of Religion of Peace for a Global Understanding." Al-Albab 5, no. 2 (2016): 237--250. https://doi.org/10.24260/alalbab.v5i2.507

Al-Qurtuby, Sumanto. Lubang Hitam Agama: Mengkritik Fundamentalisme Agama, Menggugat Islam Iunggal. Yogyakarta: Rumah Kita, 2007.

Azra, Azyumardi. Islam Nusantara: Jaringan Global Dan Lokal. Jakarta: Mizan, 2002.

Busro, Busro, and Husnul Qodim. "Perubahan Budaya Dalam Ritual Slametan Kelahiran Di Cirebon, Indonesia." Jurnal Studi Agama Dan Masyarakat 14, no. 2 (2018): https://doi.org/10.23971/jsam.v14i2.699.

Fahmi, Muhammad. "Diskursus Islam Nusantara Dalam Refresentasi Media Massa." Jurnal Komunikasi Islam 7, no. 1 (2017): 24-25.

Hamdi, Ahmad Zainul. "Radikalisme Islam Melalui Institusi Semi-Negara: Studi Kasus Atas Peran MUI Pasca-Soeharto." JurnaL Istiqra 6, no. 1 (2007): 85-126.

Ibrahim. "Hubungan Penutur Bahasa-Bahasa Melayik: Kes Suku Iban Da Melayu Di Badau, Pulau Borneo." Universiti Kebangsaan Malaysia, 2013.

Ibrahim, Ibrahim. "Al-Ṭuqūs Wa 'alāqatuhā Bi Huwīyat Muslimī Ulu Kapuas, Kalimantan Al-Gharbīyah." Studia Islamika 25, no. 3 (December 1, 2018): 543-88. https://doi.org/10.15408/sdi.v25i3.6579. 
"Contiguity of Islam and Local Tradition on the Hinterland Malays of West Kalimantan." Ulumuna 22, no. 2 (December 28, 2018): 277-300. https://doi.org/10.20414/ujis.v22i2.286.

Ibrahim, and Imron Muttaqin. "Revitalisasi Peran Tokoh Agama Dan Lembaga Keagamaan Dalam Penguatan Pesan Islam Moderat Di Wilayah Perbatasan." IAIN Pontianak, 2018.

Junaidi, Arifin. "Islam Nusantara Adalah Islam Kita." In Islam Nusantara Meluruskan Kesalahpahaman, edited by Abdurrahman Wahid. Jakarta: LP Ma`arif NU, 2015.

Khusen, Moh. "Contending Identity In The Islamic Ritual: The Slametan among Surinamese Javanese Muslims in The Netherlands." Al-Jami'ah: Journal of Islamic Studies 43, no. 2 (November 30, 2005):

283.

https://doi.org/10.14421/ajis.2005.432.28 3-308.

Muhaimin, Abdul Ghafur. "The Islamic Traditions of Cirebon." Australian National University, 2006.

Muhyiddin. "Kiai Ma'ruf Amin: Radikalisme Sekuler Ingin Agama Tak Berkontribusi Di Kehidupan." Republika Online. Accessed April 14, 2019. https://www.republika.co.id/berita/duniaislam/islamnusantara/17/03/27/onhbgc318-kiaimaruf-amin-radikalisme-sekuler-inginagama-tak-berkontribusi-di-kehidupan.

Romli, Mohamad Guntur. Islam Kita, Islam Nusantara: Lima Nilai Dasar Islam Nusantara. Tangerang: Ciputat School, 2016.

Sila, Muhammad Adlin. "Menjadi Muslim Di Bima Sumbawa Indonesia: Keanekaragaman Politik Dan Budaya." Australian National University, 2014.

Siradj, Said Aqil. "Islam Indonesia Bukan Islam Arab.” Detik News, 2015.

—. Islam Sumber Inspirasi Budaya Nusantara. Jakarta: LTN PBNU, 2015.

Sumbulih, Umi. "Gerakan Fundamentalisme Islam Di Malang: Studi Atas Hizbut
Tahrir, Majlis Mujahidin, Dan Arimatea." Jurnal Istiqra 6, no. 1 (2007): $1-50$.

Wadley, Reed L. "Community Cooperatives, 'Illegal' Logging and Regional Autonomy in the Borderlands of West Kalimantan." In State, Communities and Forests In Contemporary Borneo. ANU Press, 2006. https://doi.org/10.22459/SCFCB.07.2006 .06 .

Wadley, Reed L, and M. Eilenberg. "Vigilantes and Gangsters in the Borderland of West Kalimantan, Indonesia." State, Communities and Forests In Contemporary Borneo, 2006.

Wahid, Abdurrahman. Islam Nusantara: Meluruskan Kesalahpahaman. Jakarta: Lembaga Ma`arif PBNU, 2015.

Yusqi, Isom. "Islam Nusantara Bukan Agama Baru." In Islam Nusantara Meluruskan Kesalahpahaman, edited by Abdurrahman Wahid. Jakarta: LP Ma`arif NU, 2015.

\section{Interview}

Sukiman, interview by Ibrahim. Badau, Kapuas Hulu. May 27, 2018.

Masni, interview by Ibrahim. Badau, Kapuas Hulu. May 27, 2018.

Adeni, interview by Ibrahim. Badau, Kapuas Hulu. May 27, 2018.

Abdurrahman, interview by Ibrahim. Putussibau, Kapuas Hulu. May 28, 2018.

Shabirin, Iman, interview by Ibrahim. Putussibau, Kapuas Hulu. May 28, 2018.

Suryadi, interview by Ibrahim. Putussibau, Kapuas Hulu. May 28, 2018.

Jalaluddin, Aziz, interview by Ibrahim. Putussibau, Kapuas Hulu. May 28, 2018.

Saleh, Abang M., interview by Ibrahim. Putussibau, Kapuas Hulu. May 30, 2018.

Ibrahim, interview by Ibrahim. Putussibau, Kapuas Hulu. May 30, 2018.

Suherman, interview by Ibrahim. Putussibau, Kapuas Hulu. May 30, 2018. 